\title{
The UnIVerse AS COMMUNION
}

\section{Book Title:}

The universe as communion: Towards a neo-patristic synthesis of theology and science

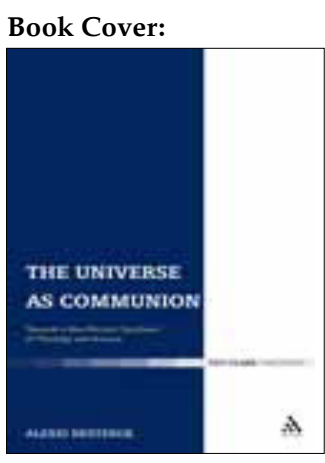

Author:

A.V. Nesteruk

ISBN:

978-0-567-03327-7

Publisher:

T\&T Clark, The

Continuum International

Publishing Group, United

Kingdom; 2008, p. 304, £75*

*Book price at time of Review

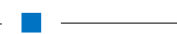

\section{Review Title:}

The universe as

communion

\section{Reviewer:}

A.K. le Roux ${ }^{1,2}$

Affiliations:

${ }^{1}$ Department of Dogmatics and Christian Ethics,

University of Pretoria,

South Africa

${ }^{2}$ Dutch Reform Church, Pretoria Congregation, South Africa

email:

akleroux@telkomsa.net

Postal address:

Susanstraat 374, Die

Wilgers 0041, South Africa

\section{How to cite this book} review:

Le Roux, A.K., 2010, The

universe as a communion,

Verbum et Ecclesia 31(1),

Art. \#402, 1 page. DOI:

10.4102/ve.v31i1.402

This review is available

at:

http://www.ve.org.za

(C) 2010. The Authors.

Licensee: OpenJournals,

Publishing. This work

is licensed under the

Creative Commons

Attribution License.
This monograph by Alexei Nesteruk, a senior lecturer in mathematics at the University of Portsmouth and a deacon in the Russian Orthodox Church, represents a distinctive approach to the science-religion debate. He describes the aim of his book as an existential exploration of the dialogue between theology and science and argues that this dialogue is only possible if scientific knowledge and faith are treated as two activities of human subjectivity. This approach is familiar to the Orthodox tradition which did not, according to Nesteruk, experience a clash between science and religion like their counterparts in the West. The fact that Eastern Christianity had a different experience of the relation between religion and science is the platform from which Nesteruk departs and it is from this platform that he wants to shed new light on the contemporary debate. He explains this insight by focussing on those aspects of Eastern and Western Christianity which share a common ground - namely, in the writings of the Early Church Fathers. They defended the Christian faith against an atheist environment in a similar manner to the present day and therefore can offer guidelines for modern theological development. These guidelines become effective through what Nesteruk calls a neo-patristic synthesis in contemporary theology. The first two chapters of the book explain how such a synthesis is possible by relating premodern theological convictions to the postmodern philosophical approach of existential phenomenology.

The next chapter deals with the value of a phenomenological attitude for theology and how the patristic truths can be rediscovered through this approach. From this perspective, theology and science are two different activities of human subjectivity. The mediation between them lies in the unity of the human experience. Phenomenology becomes the perspective from which theology and science can be compared from within their function in human subjectivity as two distinct intentionalities. When both are treated as modes of conscious experience, the reconciliation between them becomes the experienced reality of a specific person.

In the last two chapters of the book, Nesteruk reflects on the limitations of the scientific approach as seen from a phenomenological perspective. Scientific knowledge, like any other knowledge, is knowledge of phenomena and displays subjectivity. The natural universe, as described in terms of mathematics, is a human achievement. Nature is not an a priori given to human observers, but reconstructed through phenomena. Any attempt to proclaim the ultimate and objective sense through abstraction from acts of human subjectivity represents a distortion of the natural order. According to the phenomenological approach, the understanding of nature originates from human existence. Knowledge of an objective reality, which exists outside and independent of human insight is, as such, a fallacy. In accordance with Husserl, Nesteruk refers to the ultimate paradox of being. The fact that humans are part of the world, but at the same time constitute the consciousness of the world, is a dichotomy that must be accepted as a given, as the primary existential reality. This human element brings something unique to existence, which natural science cannot identify. Science is not sufficient to understand what it means to be human.

With this subjective element in mind, the act of knowing becomes much more personal. The word communion is Nesteruk's way of acknowledging how knowing someone or something, even the universe, involves a personal act of acknowledgement. Scientific knowledge, just like faith, is a mode of communion and is always an act of a particular person. The personal act of knowing and experience is unique to every person and it is in the personhood of an individual that the reconciliation between the two modes of communion takes place.

Not everyone will appreciate Nesteruk's phenomenological approach. Some might even say that it is a tactic which makes his view immune against critique from the natural sciences and that, given his views, the debate between science and religion is impossible. However, in reading this book the reader will become aware that the debate between science and religion will always reveal a personal point of view, which must be acknowledged in the debate. Nesteruk's arguments are not easy to follow, because they presuppose familiarity with phenomenology and he tends to labour arguments that are already well-established. However, the greatest value of this book is the fact that the reader becomes aware of his or her personal involvement in the act of knowing. The awareness of this personal, interpretative act makes those who take part in the debate between science and religion more modest and aware of the amount of personal freedom allowed in the debate. Arguments between conflicting views will never be settled by pure reasoning because of the potential of more than one mode of communion within the same person. Rather, the arguments are settled within the same person who chooses more than one intentionality. This perspective of Nesteruk regarding different intentionalities is crucial in the debate between orthodoxy and the so-called critical approaches in theology. The pretence that takes the critical approaches to abstract issues of faith to the level of objectivity reveals a mindset that approaches theology with a natural scientific intentionality. Nesteruk shows correctly that alternatives are always possible and that the critical approach in theology is just as subjective and personal as commitments of faith. 